\title{
Timing of immune checkpoint inhibitors for metastatic patients over 75 years of age: the earlier the better
}

Thierry Landre ( $\nabla$ thierry.landre@aphp.fr)

APHP

\section{Gaetan Des Guetz}

$\mathrm{CH}$ Delafontaine St Denis

Kader Chouahnia

Hopital Avicenne

Virginie Fossey-Diaz

Hopital Bretonneau

Stéphane Culine

Hopital Saint Louis

\section{Research}

Keywords: Cancer, Immune Checkpoint, PD-L1, PD-1, CTLA-4, Older, Meta-Analysis

Posted Date: May 7th, 2020

DOI: https://doi.org/10.21203/rs.3.rs-26423/v1

License: (c) (i) This work is licensed under a Creative Commons Attribution 4.0 International License. Read Full License 


\section{Abstract}

Background The impact of ageing on Immune Checkpoint Inhibitors (ICls) effectiveness remains controversial. However, data from clinical studies do not show any difference between patients over 65 years and those under 65 years. We focused our study on patients over 75 and looked at the potential impact of timing in the use of ICls.

Methods We performed a meta-analysis of published randomized control trials (RCTs) concerning ICls versus standard therapy in patients with advanced solid tumors. Overall Survival (OS) among the older ( $\geq 75$ years) was compared with that of younger patients ( $<75$ years). Hazard ratios (HRs) with their $95 \%$ confidence interval (CI) were collected and pooled.

Results Fifteen phase III studies evaluating anti-PD-1(nivolumab or pembrolizumab), anti-PD-L1 (atezolizumab or avelumab) or anti-CTLA-4 (ipilimumab) were included. Patients were enrolled for Non-Small-Cell-Lung-Cancer, Renal-Cell-Carcinoma, Melanoma, Head-and-Neck-Squamous-Cell-Carcinoma or Gastric Cancer. Eight studies assessed treatment in first-line setting and seven in the second line. The median age was 64 years, with 906 patients over 75 years of age and 5233 youngers. In first-line setting, HRs for death were 0.78 (95\% Cl: 0.61 $0.99)$ in patients $\geq 75$ years versus 0.84 (95\% Cl: $0.71-1.00)$ in younger. In second line setting, HRs for death were 1.02 (95\% Cl: $0.77-1.36)$ in patients $\geq 75$ years versus 0.68 (95\% Cl: $0.61-0.75)$ in younger with a statistically significant difference observed between subgroups $(p$ interaction $=0.009)$.

Conclusions ICls appears to be effective in patients over 75 years of age. However, the survival benefit is mainly observed in first-line treatment.

\section{Introduction}

Immune Checkpoint Inhibitors (ICls), such as anti-programmed cell death 1 (anti-PD-1), anti-programmed cell death ligand 1 (anti-PD-L1), and anti-cytotoxic T lymphocyte antigen 4 pathways (anti-CTLA-4), represent a significant step forward in cancer treatment. ICls have actually changed the outcomes for several metastatic cancers including, lung cancer, melanoma, renal cell carcinoma and many other tumors. However, few specific data have been published so far in the elderly population. Several meta-analyses compared the clinical efficacy of ICls between young and elderly patients $(1-3)$. Although they showed no difference between the two groups, the chosen cut-off age of 65 clearly is not representative of the elderly population. Therefore, we conducted a systemic review and study-level meta-analysis of randomized controlled trials (RCTs) to compare the benefit of ICls between patients under 75 years of age and those over 75 years of age.

\section{Methods}

Research strategy: We performed a meta-analysis according to a predefined written protocol. Eligible studies included patients more than 75 years old with advanced cancer having a treatment either with $\mathrm{ICI}$ (or addition of other therapies to ICI) versus "standard of care". Only randomized phase III controlled trials comparing these 2 treatment modalities were included. They compared benefits and risks of both treatment modalities concerning overall survival (OS). Publications included in this meta-analysis were identified by an electronic PubMed search updated on January 2020 using the following keywords: "RCT", "phase III", "nivolumab", "pembrolizumab", 
"atezolizumab", "durvalumab", "avelumab", "ipilimumab" and "tremelimumab", We tried to obtain additional references by cross-checking the available publications. We also searched for abstracts in the proceedings of American Society of Clinical Oncology (ASCO) (2015-2019) and European Society of Medical Oncology (ESMO) (2015-2019) conferences. An EMBASE query did not bring additional references. We did not find a systematic review on this topic in the Cochrane database. As scheduled in a written protocol, each article was carefully read by 3 reviewers (T.L., G.D.G., and S.C.). Disagreements were resolved by discussion between all authors of this meta-analysis.

Data extraction: Data extracted from eligible studies included study characteristics (first author, year of publication, treatments arms); study population (median age, characteristics of cancers, line of treatment, number of patients under 75 years of age and number of patients over 75 years of age in each treatment arm). We also collected Hazard Ratios (HRs) for Overall Survival (OS) based on age subgroups (younger vs $\geq$ 75 years).

Statistical analyses: The Cochrane collaboration method for meta-analysis, using the Review Manager software (RevMan version 5.3; Oxford, UK), was applied to compute the analyses. Statistical heterogeneity was assessed with $\chi^{2}$ tests and $R$ statistics, with a $\chi^{2}$ test $p<0.05$ indicating heterogeneity and $R$ values of $30-60 \%$ corresponding to moderate heterogeneity. A fixed effect model was used to calculate the cumulative hazard ratio (HR) when heterogeneity among studies was weak and a random model was applied when that heterogeneity was marked. Subgroup analyses were run each time for the different line setting. Meta-analysis results with $95 \%$ confidence interval $(\mathrm{Cl})$ are reported HRs for OS. Differences in the HRs between the younger and older groups were assessed using $\mathrm{Chi}^{2}$ test. All tests were two sided and $p<0.05$ defined significance.

\section{Results}

We identified 193 references that met our clinical trial selection criteria (Flow chart 1). Seventeen studies were reviewed, however 2 of these 17 studies were excluded because they did not contain subgroup analysis for age over $75(4,5)$. The final analysis included 15 studies: 8 studies in first line and 7 studies in second-line or more (Table 1). Eight studies concerned an anti-PD-1 agent (4 with nivolumab and 4 with pembrolizumab), 3 studies an anti-PD-L1 (2 with avelumab and 1 with atezolizumab), 2 studies a combination of anti-PD-1 + anti CTLA-4 (nivolumab and ipilimumab) and 2 studies a combination of anti-CTLA-4 + chemotherapy (ipilimumab + chemotherapy). Tumor types were lung cancer in ten trials (6-15) with nine studies in NSCLC, renal cancer in 2 $(16,17)$, melanoma in one (18), gastric in one (19), and head and neck cancer in one trial (20). The median age was 64 years. Overall, 906 patients $(14,8 \%)$ were older 75 years of age when $5233(85,2 \%)$ were younger 75 years of age. 
Table 1

included studies in this meta-analysis

\begin{tabular}{|c|c|c|c|c|c|c|c|}
\hline Study & Cancer & $\begin{array}{l}\text { Experimental } \\
\text { arm }\end{array}$ & Control arm & line & $\begin{array}{l}75 \text { years } \\
(\%)\end{array}$ & $<=75$ years & reference \\
\hline $\begin{array}{l}\text { Checkmate } \\
066\end{array}$ & Melanoma & nivolumab & dacarbazine & 1 & $\begin{array}{l}67 \\
(16.0)\end{array}$ & 351 & (18) \\
\hline $\begin{array}{l}\text { Govindan } \\
\text { et al } 2017\end{array}$ & NSCLC & $\begin{array}{l}\text { ipilimumab + } \\
\text { platinum based } \\
\text { chemotherapy }\end{array}$ & $\begin{array}{l}\text { platinum } \\
\text { based } \\
\text { chemotherapy }\end{array}$ & 1 & $\begin{array}{l}71 \\
(9.5)\end{array}$ & 678 & (8) \\
\hline $\begin{array}{l}\text { Keynote } \\
024\end{array}$ & NSCLC & pembrolizumab & $\begin{array}{l}\text { platinum } \\
\text { based } \\
\text { chemotherapy }\end{array}$ & 1 & $\begin{array}{l}45 \\
(14.7)\end{array}$ & 260 & (25) \\
\hline $\begin{array}{l}\text { Keynote } \\
042\end{array}$ & NSCLC & pembrolizumab & $\begin{array}{l}\text { platinum } \\
\text { based } \\
\text { chemotherapy }\end{array}$ & 1 & $\begin{array}{l}129 \\
(10.1)\end{array}$ & 1145 & (25) \\
\hline $\begin{array}{l}\text { Checkmate } \\
227\end{array}$ & NSCLC & $\begin{array}{l}\text { nivolumab + } \\
\text { ipilimumab }\end{array}$ & $\begin{array}{l}\text { platinum } \\
\text { based } \\
\text { chemotherapy }\end{array}$ & 1 & $\begin{array}{l}81 \\
(10.0)\end{array}$ & 712 & (10) \\
\hline $\begin{array}{l}\text { Impower } \\
110\end{array}$ & NSCLC & atezolizumab & $\begin{array}{l}\text { platinum } \\
\text { based } \\
\text { chemotherapy }\end{array}$ & 1 & $\begin{array}{l}22 \\
(10.7)\end{array}$ & 182 & (13) \\
\hline $\begin{array}{l}\text { Javelin } \\
\text { Lung } 200\end{array}$ & NSCLC & avelumab & doxetaxel & 2 & $\begin{array}{l}50 \\
(9.4)\end{array}$ & 479 & (9) \\
\hline $\begin{array}{l}\text { Keynote } \\
010\end{array}$ & NSCLC & pembrolizumab & docetaxel & 2 & $\begin{array}{l}90 \\
(8.7)\end{array}$ & 943 & (25) \\
\hline $\begin{array}{l}\text { Checkmate } \\
017\end{array}$ & NSCLC & nivolumab & docetaxel & 2 & $\begin{array}{l}29 \\
(10.7)\end{array}$ & 243 & (6) \\
\hline $\begin{array}{l}\text { Checkmate } \\
057\end{array}$ & NSCLC & nivolumab & docetaxel & 2 & $43(7.4)$ & 539 & (14) \\
\hline $\begin{array}{l}\text { Checkmate } \\
214\end{array}$ & $\mathrm{RCC}$ & $\begin{array}{l}\text { nivolumab + } \\
\text { ipilimumab }\end{array}$ & sunitinib & 1 & $65(7.7)$ & 782 & (17) \\
\hline $\begin{array}{l}\text { Checkmate } \\
025\end{array}$ & $\mathrm{RCC}$ & nivolumab & everolimus & 2 & $74(9.0)$ & 747 & (16) \\
\hline $\begin{array}{l}\text { Reck et al } \\
2016\end{array}$ & SCLC & $\begin{array}{l}\text { ipilimumab + } \\
\text { etoposide- } \\
\text { platinum }\end{array}$ & $\begin{array}{l}\text { etoposide- } \\
\text { platinum }\end{array}$ & 1 & $72(7.5)$ & 882 & (7) \\
\hline
\end{tabular}

CT: chemotherapy, HNSCC: Head and Neck squamous cell carcinoma, NSCLC non-small-cell-lung-cancer, RCC: renal cell cancer, SCLC small-cell-lung-cancer, $1 \mathrm{~L}$ first-line, $2 \mathrm{~L}$ second-line

Flow chart of the meta-analysis 


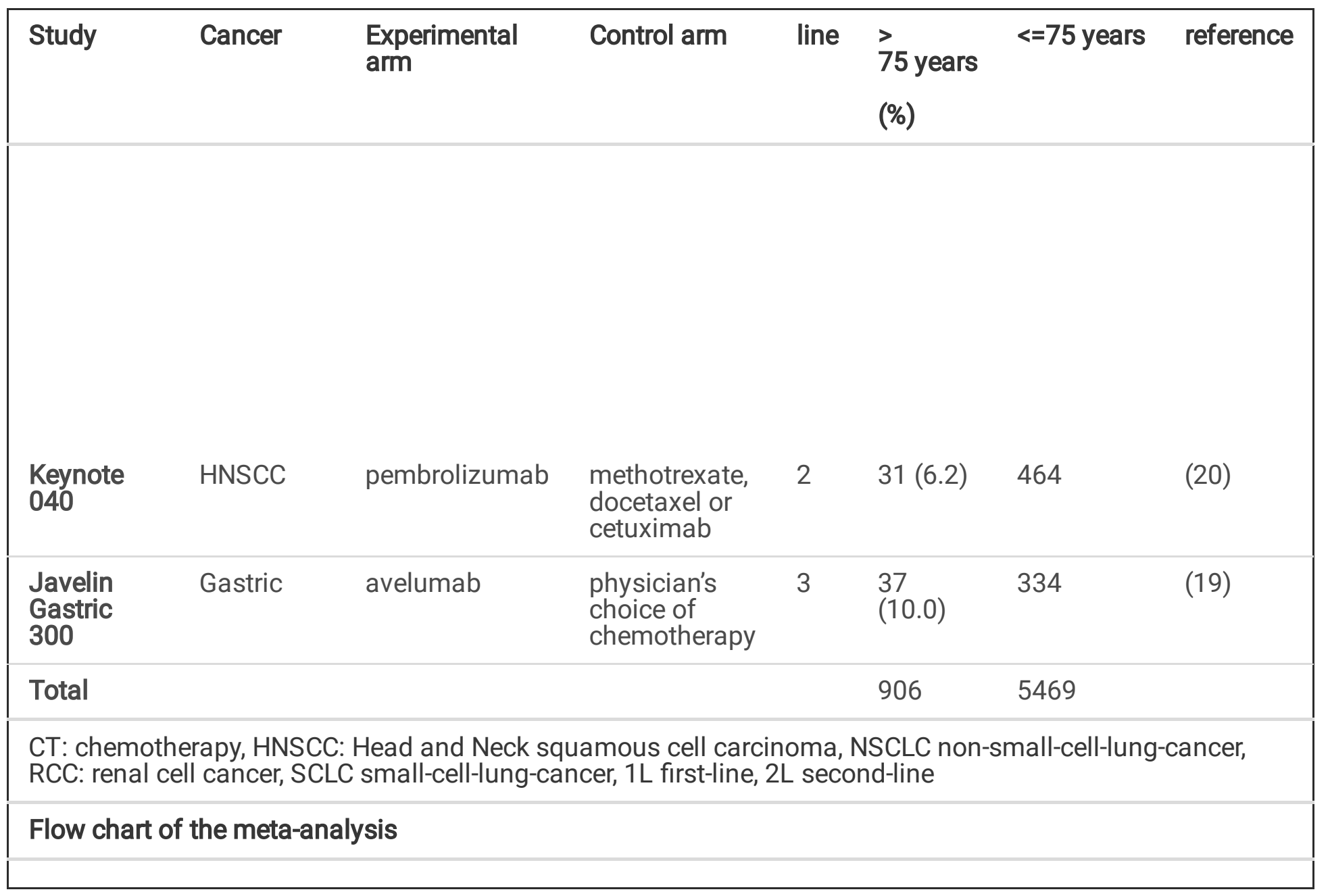

ICls shows a statistically significant survival benefit compared to standard treatments $(\mathrm{HR}: 0.78,95 \% \mathrm{Cl}, 0.68-$ $0.89, p=0.0003)$ for younger patients, but not for patients over 75 years of age (HR: $0.86,95 \% \mathrm{Cl}, 0.72-1.02, p=$ 0.08 ) (Fig. 1). The heterogeneity interaction test was not statistically significant (interaction for age subgroup: $p$ $=0.39$ ). Meta-analysis for first-line setting was based on 8 studies ( 6 concerning lung cancer, 1 melanoma and 1 renal cancer). A survival benefit of ICls compared to standard treatments was shown (HR: $0.84,95 \% \mathrm{Cl}, 0.71$ $1.00, p=0.05)$ for younger patients, as well as for patients over 75 year-old (HR: $0.78,95 \% \mathrm{Cl}, 0.61-0.99, p=$ 0.04) (Fig. 2). The heterogeneity interaction test was not statistically significant in first line setting (interaction for age subgroup: $P=0.58$ ). Meta-analysis for second-line setting was based on 6 studies. In terms of $O S, a$ statistically significant benefit of ICls compared to standard treatments was shown (HR: $0.68,95 \% \mathrm{Cl}, 0.61-$ $0.75, p<0.00001$ ) for younger patients, but there was no benefit for patients over 75 years old. (HR: $1.02,95 \% \mathrm{Cl}$, $0.77-1.36, p=0.88$ ) (Fig. 3). The heterogeneity interaction test was statistically significant in second-line setting (Interaction for age subgroup $\mathrm{Chi}^{2}=6.92, \mathrm{P}=0.009$ ).

\section{Discussion}

ICls provide interesting response rates in many tumors and maintain a better quality of life than other anticancer therapies. As older patients are more fragile than younger because of frequent comorbidities and organic failures, the therapeutic option of immunotherapy is particularly attractive in this population. However, no randomized study has been reported so far in the elderly population. Therefore, meta-analyses are an interesting approach to identify trends and generate working hypotheses. In the meta-analysis by Nishijima et al., 5 RCTs 
with anti-PD-1 agents and 4 with anti-CTLA-4 agents were retained, with a cut-off of 65 years (1). OS and PFS benefit were shown without difference between age-group. The meta-analysis by Elias et al. focused on 9 RCTs with anti-PD-1 and anti-PDL-1 agents, with a cut-off of 65 years of age (2). Conclusions were similar to those of Nishijima et al. More recently,

Ninomiya et al. published a meta-analysis including of 24 studies for anti-CTLA-4 and anti-PD(L)-1, with a cutoff at 65 years of age. A lower efficacy of anti-CTLA-4 in the elderly was reported without any difference in OS depending on the location of the primary or the line of treatment (3). Finally, the meta-analysis by Li et al. had several cut-offs of age (under 65, over 65, over 75). For patients over 75 years, 8 studies were retained, and no OS benefit was observed (21). Overall the impact of ageing on ICls effectiveness therefore remains controversial.

To the best in our knowledge, we report the first meta-analysis assessing efficacy of ICls in patients over the age of 75. A benefit on OS was observed for both younger and older patients. However, the overall benefit $(\mathrm{HR}=$ $0.86)$ observed in the elderly is of borderline significance $(p=0.08)$. This is likely due to the small numbers of patients over the age of 75 included in each study. Second, the meta-analysis showed differences depending on the timing of ICls. In first-line setting, the benefit was statistically significant $(p=0.04)$ for the elderly and similar in younger patients (heterogeneity $P=0.58)$. In second-line setting, there was no benefit in elderly patients $(p=$ 0.88 ) while the benefit remained significant in younger patients (heterogeneity $P=0,009$ ). From a biological point of view, ageing is known to dramatically affect the normal cells of the tumor microenvironment. Ageinduced immunosenescence occurs in effector $T$ cells and other immune cell types crucial for tumour immunity. These changes are supposed to induce a shift towards the activation and infiltration of more immunosuppressive cell populations in the elderly, such as M2-like immunosuppressive macrophages.(22). As chemotherapy has also been shown to further accelerate this process, it could be assumed that using first-line treatment before immunotherapy could decrease the likelihood of checkpoint inhibitor efficacy.

Our study has several limits. First, it concerns different types of cancers. As the efficacy of ICls appears very different depending on the tumor type, the impact of ICls and their timing could be different. Second, the population of elderly patients who are included in RCT is obviously selected and is not representative of patients managed in daily practice. The question whether our observations could be applied to more frail patients remains to be answered. Third, our study concerns different drugs or different drug combinations. Finally, it should be noted that for some studies, patients were selected on tumor/immune cells expression levels of PDL1 that could interfere for treatment decisions in older patients.

What could be the consequences for the daily management of elderly patients according to primary tumors? For melanoma patients, Checkmate 066 study and additional cohort studies of patients aged over 80 have confirmed the benefit of ICls $(23,24)$. The only issue is to consider or not the addition of an anti-CTLA-4 agent according to the geriatric assessment. In patients with non-oncogenic driven NSCLC, the standard of care is a combination of chemotherapy and anti-PD-1 agent. In frail patients, immunotherapy alone could be the optimal option considering the side effects of chemotherapy and tumor/immune cells expression levels of PDL-1. In renal cell cancer, current standard first-line treatments for intermediate-risk and poor-risk are based on combinations with either anti-CTLA-4 and anti-PD-1 agents or anti-PD- 1 and anti-VEGF-R agents. Such combinations may be unsuitable because of frailty. The question whether an anti-PD-1 agent alone could be used remains to be validated. 


\section{Conclusion}

Physiological aging is associated with changes in immune system response. Our study highlights the fact that the clinical benefit of ICls in patients over 75 years of age may be predominantly retained in the first-line treatment of metastatic diseases. Different immunotherapy combination strategies or combination of chemotherapy with immunotherapy should be considered for older patients to improve clinical efficacy in second line setting. Exploring the molecular and immune mechanisms represents a tough challenge for future study in this field of cancer treatment.

\section{Declarations}

\section{Conflicts of interest/Competing interests:}

The authors declare that they have no conflicts of interest relating to this article.

\section{Role of the funding source}

This study was not funded by any sponsors.

\section{Authorship}

TL designed research, collected data, analyzed and interpreted data, and wrote the manuscript. GDG and SC contributed to collection of data and revision of the manuscript. VFD and KC participated in the elaboration of the research design and revision of the manuscript.

\section{Funding}

None.

\section{References}

1. Nishijima TF, Muss HB, Shachar SS, Moschos SJ. Comparison of efficacy of immune checkpoint inhibitors (ICls) between younger and older patients: A systematic review and meta-analysis. Cancer Treat Rev. 2016 Apr;45:30-7.

2. Elias R, Giobbie-Hurder A, McCleary NJ, Ott P, Hodi FS, Rahma O. Efficacy of PD-1 \& PD-L1 inhibitors in older adults: a meta-analysis. J Immunother Cancer. 2018;04(1):26. 6(.

3. Ninomiya K, Oze I, Kato Y, Kubo T, Ichihara E, Rai K, et al. Influence of age on the efficacy of immune checkpoint inhibitors in advanced cancers: a systematic review and meta-analysis. Acta Oncol Stockh Swed. 2020 Mar;59(3):249-56.

4. Ferris RL, Blumenschein G, Fayette J, Guigay J, Colevas AD, Licitra L, et al. Nivolumab for Recurrent Squamous-Cell Carcinoma of the Head and Neck. N Engl J Med. 2016;10(19):1856-67. 375(.

5. Kang Y-K, Boku N, Satoh T, Ryu M-H, Chao Y, Kato K, et al. Nivolumab in patients with advanced gastric or gastro-oesophageal junction cancer refractory to, or intolerant of, at least two previous chemotherapy regimens (ONO-4538-12, ATTRACTION-2): a randomised, double-blind, placebo-controlled, phase 3 trial. Lancet Lond Engl. 2017 Dec 2;390(10111):2461-71. 
6. Brahmer J, Reckamp KL, Baas P, Crinò L, Eberhardt WEE, Poddubskaya E, et al. Nivolumab versus Docetaxel in Advanced Squamous-Cell Non-Small-Cell Lung Cancer. N Engl J Med. 2015 Jul;9(2):123-35. 373(.

7. Reck M, Luft A, Szczesna A, Havel L, Kim S-W, Akerley W, et al. Phase III Randomized Trial of Ipilimumab Plus Etoposide and Platinum Versus Placebo Plus Etoposide and Platinum in Extensive-Stage Small-Cell Lung Cancer. J Clin Oncol Off J Am Soc Clin Oncol. 2016;01(31):3740-8. 34(.

8. Govindan R, Szczesna A, Ahn M-J, Schneider C-P, Gonzalez Mella PF, Barlesi F, et al. Phase III Trial of Ipilimumab Combined With Paclitaxel and Carboplatin in Advanced Squamous Non-Small-Cell Lung Cancer. J Clin Oncol Off J Am Soc Clin Oncol. 2017 Oct;20(30):3449-57. 35(.

9. Barlesi F, Vansteenkiste J, Spigel D, Ishii H, Garassino M, de Marinis F, et al. Avelumab versus docetaxel in patients with platinum-treated advanced non-small-cell lung cancer (JAVELIN Lung 200): an open-label, randomised, phase 3 study. Lancet Oncol. 2018 Sep 21.

10. Hellmann MD, Paz-Ares L, Bernabe Caro R, Zurawski B, Kim S-W, Carcereny Costa E, et al. Nivolumab plus Ipilimumab in Advanced Non-Small-Cell Lung Cancer. N Engl J Med. 2019 Sep 28.

11. Herbst RS, Baas P, Kim D-W, Felip E, Pérez-Gracia JL, Han J-Y, et al. Pembrolizumab versus docetaxel for previously treated, PD-L1-positive, advanced non-small-cell lung cancer (KEYNOTE-010): a randomised controlled trial. Lancet Lond Engl. 2016 Apr 9;387(10027):1540-50.

12. Mok TSK, Wu Y-L, Kudaba I, Kowalski DM, Cho BC, Turna HZ, et al. Pembrolizumab versus chemotherapy for previously untreated, PD-L1-expressing, locally advanced or metastatic non-small-cell lung cancer (KEYNOTE-042): a randomised, open-label, controlled, phase 3 trial. Lancet Lond Engl. 2019;04(10183):1819-30. 393(.

13. $10.1093 /$ annonc/mdz293/5577589

Spigel D, de Marinis F, Giaccone G, Reinmuth N, Vergnenegre A, Barrios CH, et al. LBA78IMpower110: Interim overall survival (OS) analysis of a phase III study of atezolizumab (atezo) vs platinum-based chemotherapy (chemo) as first-line (1L) treatment (tx) in PD-L1-selected NSCLC. Ann Oncol [Internet]. 2019 Oct 1 [cited 2019 Nov 20];30(Supplement_5). Available from:

https://academic.oup.com/annonc/article/doi/10.1093/annonc/mdz293/5577589.

14. Borghaei H, Paz-Ares L, Horn L, Spigel DR, Steins M, Ready NE, et al. Nivolumab versus Docetaxel in Advanced Nonsquamous Non-Small-Cell Lung Cancer. N Engl J Med. 2015 Oct;22(17):1627-39. 373(.

15. Reck M, Rodríguez-Abreu D, Robinson AG, Hui R, Csőszi T, Fülöp A, et al. Pembrolizumab versus Chemotherapy for PD-L1-Positive Non-Small-Cell Lung Cancer. N Engl J Med. 2016;10(19):1823-33. 375(.

16. Motzer RJ, Escudier B, McDermott DF, George S, Hammers HJ, Srinivas S, et al. Nivolumab versus Everolimus in Advanced Renal-Cell Carcinoma. N Engl J Med. 2015 Nov;5(19):1803-13. 373(.

17. Motzer RJ, Tannir NM, McDermott DF, Arén Frontera O, Melichar B, Choueiri TK, et al. Nivolumab plus Ipilimumab versus Sunitinib in Advanced Renal-Cell Carcinoma. N Engl J Med. 2018;05(14):1277-90. 378(.

18. Robert C, Long GV, Brady B, Dutriaux C, Maio M, Mortier L, et al. Nivolumab in previously untreated melanoma without BRAF mutation. N Engl J Med. 2015 Jan;22(4):320-30. 372(.

19. Bang Y-J, Ruiz EY, Van Cutsem E, Lee K-W, Wyrwicz L, Schenker M, et al. Phase 3, randomised trial of avelumab versus physician's choice of chemotherapy as third-line treatment for patients with advanced gastric or gastro-oesophageal junction cancer: primary analysis of JAVELIN Gastric 300. Ann Oncol Off J Eur Soc Med Oncol. 2018 Jul 24. 
20. Cohen EEW, Soulières D, Le Tourneau C, Dinis J, Licitra L, Ahn M-J, et al. Pembrolizumab versus methotrexate, docetaxel, or cetuximab for recurrent or metastatic head-and-neck squamous cell carcinoma (KEYNOTE-040): a randomised, open-label, phase 3 study. Lancet Lond Engl. 2018 Nov 30.

21. Li J, Gu J. Efficacy of immune checkpoint inhibitors in cancer patients of different ages: a meta-analysis. Future Oncol Lond Engl. 2019 Nov;15(31):3633-46.

22. Fane M, Weeraratna AT. How the ageing microenvironment influences tumour progression. Nat Rev Cancer. 2020 Feb;20(2):89-106.

23. Bastholt L, Schmidt H, Bjerregaard JK, Herrstedt J, Svane IM. Age favoured overall survival in a large population-based Danish patient cohort treated with anti-PD1 immune checkpoint inhibitor for metastatic melanoma. Eur J Cancer Oxf Engl 1990. 2019 Sep;119:122-31.

24. Ibrahim T, Mateus C, Baz M, Robert C. Older melanoma patients aged 75 and above retain responsiveness to anti-PD1 therapy: results of a retrospective single-institution cohort study. Cancer Immunol Immunother CII. 2018 Oct;67(10):1571-8.

25. Nosaki K, Saka H, Hosomi Y, Baas P, de Castro G, Reck M, et al. Safety and efficacy of pembrolizumab monotherapy in elderly patients with PD-L1-positive advanced non-small-cell lung cancer: Pooled analysis from the KEYNOTE-010, KEYNOTE-024, and KEYNOTE-042 studies. Lung Cancer Amst Neth. 2019 Sep;135:188-95.

\section{Figures}


Hazard Ratio

Study or Subgroup

1.1.1 Under 75 years

Checkmate 066

Checkmate 017

Keynote 040

Checkmate 057

Impower 110

Checkmate 025

Keynote 024

Keynote 010

Keynote 042

Checkmate 214

Javelin Lung 200

Checkmate 227

Govindan 2017

Reck 2016

Javelin Gastric 300

Subtotal $(95 \% \mathrm{Cl})$

Heterogeneity: $\mathrm{Tau}^{2}=0.04 ; \mathrm{Chi}^{2}=42.43, \mathrm{df}=14(\mathrm{P}=0.0001) ; \mathrm{I}^{2}=67 \%$

Test for overall effect: $Z=3.64(P=0.0003)$

\subsubsection{Over 75 years}

$\begin{array}{lrr}\text { Checkmate 066 } & 1.2 \% & 0.25[0.10,0.62] \\ \text { Keynote 024 } & 0.9 \% & 0.49[0.17,1.41] \\ \text { Reck 2016 } & 2.5 \% & 0.70[0.40,1.22] \\ \text { Keynote 010 } & 2.9 \% & 0.72[0.43,1.21] \\ \text { Javelin Gastric 300 } & 1.3 \% & 0.72[0.31,1.67] \\ \text { Govindan 2017 } & 2.9 \% & 0.85[0.51,1.42] \\ \text { Keynote 042 } & 3.8 \% & 0.89[0.59,1.34] \\ \text { Checkmate 057 } & 1.7 \% & 0.90[0.43,1.88] \\ \text { Checkmate 227 } & 3.1 \% & 0.92[0.57,1.49] \\ \text { Checkmate 214 } & 1.8 \% & 0.97[0.48,1.96] \\ \text { Impower } 110 & 0.4 \% & 1.04[0.19,5.69] \\ \text { Keynote 040 } & 1.0 \% & 1.13[0.42,3.04] \\ \text { Javelin Lung 200 } & 1.6 \% & 1.16[0.54,2.49] \\ \text { Checkmate 025 } & 2.2 \% & 1.23[0.66,2.29] \\ \text { Checkmate 017 } & 1.2 \% & 1.85[0.76,4.50] \\ \text { Subtotal (95\% Cl) } & \mathbf{2 8 . 5 \%} & \mathbf{0 . 8 6}[0.72,1.02]\end{array}$

Heterogeneity: $\mathrm{Tau}^{2}=0.00 ; \mathrm{Chi}^{2}=14.49, \mathrm{df}=14(\mathrm{P}=0.41) ; \mathrm{I}^{2}=3 \%$

Test for overall effect: $Z=1.73(P=0.08)$

\section{Total $(95 \% \mathrm{Cl})$}

$100.0 \%$

$0.80[0.72,0.89]$

Heterogeneity: $\mathrm{Tau}^{2}=0.03 ; \mathrm{Chi}^{2}=57.69, \mathrm{df}=29(\mathrm{P}=0.001) ; \mathrm{I}^{2}=50 \%$

Test for overall effect: $Z=4.02(P<0.0001)$

Test for subgroup differences: $\mathrm{Chi}^{2}=0.73, \mathrm{df}=1(\mathrm{P}=0.39), \mathrm{I}^{2}=0 \%$
Hazard Ratio

IV, Random, $95 \% \mathrm{Cl}$

\section{Figure 1}

Meta-Analysis of Overall Survival: (1) under the age of 75 (2) over the age of 75 
Hazard Ratio

Weight IV, Random, $95 \% \mathrm{Cl}$

Study or Subgroup

1.1.1 Under 75 years

Checkmate 066

Impower 110

Keynote 024

Keynote 042

Checkmate 214

Checkmate 227

Govindan 2017

Reck 2016

Subtotal $(95 \% \mathrm{Cl})$

$3.9 \%$

$3.8 \%$

$0.44[0.24,0.81]$

$6.7 \%$

$0.63[0.34,1.17]$

$16.0 \%$

$7.3 \%$

$11.3 \%$

$11.1 \%$

$11.0 \%$

$71.0 \%$

Heterogeneity: $\mathrm{Tau}^{2}=0.03 ; \mathrm{Chi}^{2}=15.46, \mathrm{df}=7(\mathrm{P}=0.03) ; \mathrm{I}^{2}=55 \%$

Test for overall effect: $Z=2.00(P=0.05)$

\subsubsection{Over 75 years}

$\begin{array}{lrr}\text { Checkmate 066 } & 1.9 \% & 0.25[0.10,0.62] \\ \text { Keynote 024 } & 1.5 \% & 0.49[0.17,1.41] \\ \text { Reck 2016 } & 4.4 \% & 0.70[0.40,1.22] \\ \text { Govindan 2017 } & 5.1 \% & 0.85[0.51,1.42] \\ \text { Keynote 042 } & 6.9 \% & 0.89[0.59,1.34] \\ \text { Checkmate } 227 & 5.6 \% & 0.92[0.57,1.49] \\ \text { Checkmate } 214 & 3.0 \% & 0.97[0.48,1.96] \\ \text { Impower } 110 & 0.6 \% & 1.04[0.19,5.69] \\ \text { Subtotal }(95 \% \mathrm{Cl}) & \mathbf{2 9 . 0 \%} & \mathbf{0 . 7 8}[0.61,0.99]\end{array}$

Heterogeneity: $\mathrm{Tau}^{2}=0.02 ; \mathrm{Chi}^{2}=8.24, \mathrm{df}=7(\mathrm{P}=0.31) ; \mathrm{I}^{2}=15 \%$

Test for overall effect: $Z=2.06(P=0.04)$

Total $(95 \% \mathrm{Cl})$

$100.0 \%$

$0.83[0.72,0.94]$

Heterogeneity: $\mathrm{Tau}^{2}=0.02 ; \mathrm{Chi}^{2}=24.15, \mathrm{df}=15(\mathrm{P}=0.06) ; \mathrm{I}^{2}=38 \%$

Test for overall effect: $Z=2.83(P=0.005)$

Test for subgroup differences: $\mathrm{Chi}^{2}=0.30, \mathrm{df}=1(\mathrm{P}=0.58), \mathrm{I}^{2}=0 \%$
Hazard Ratio

IV, Random, $95 \% \mathrm{CI}$

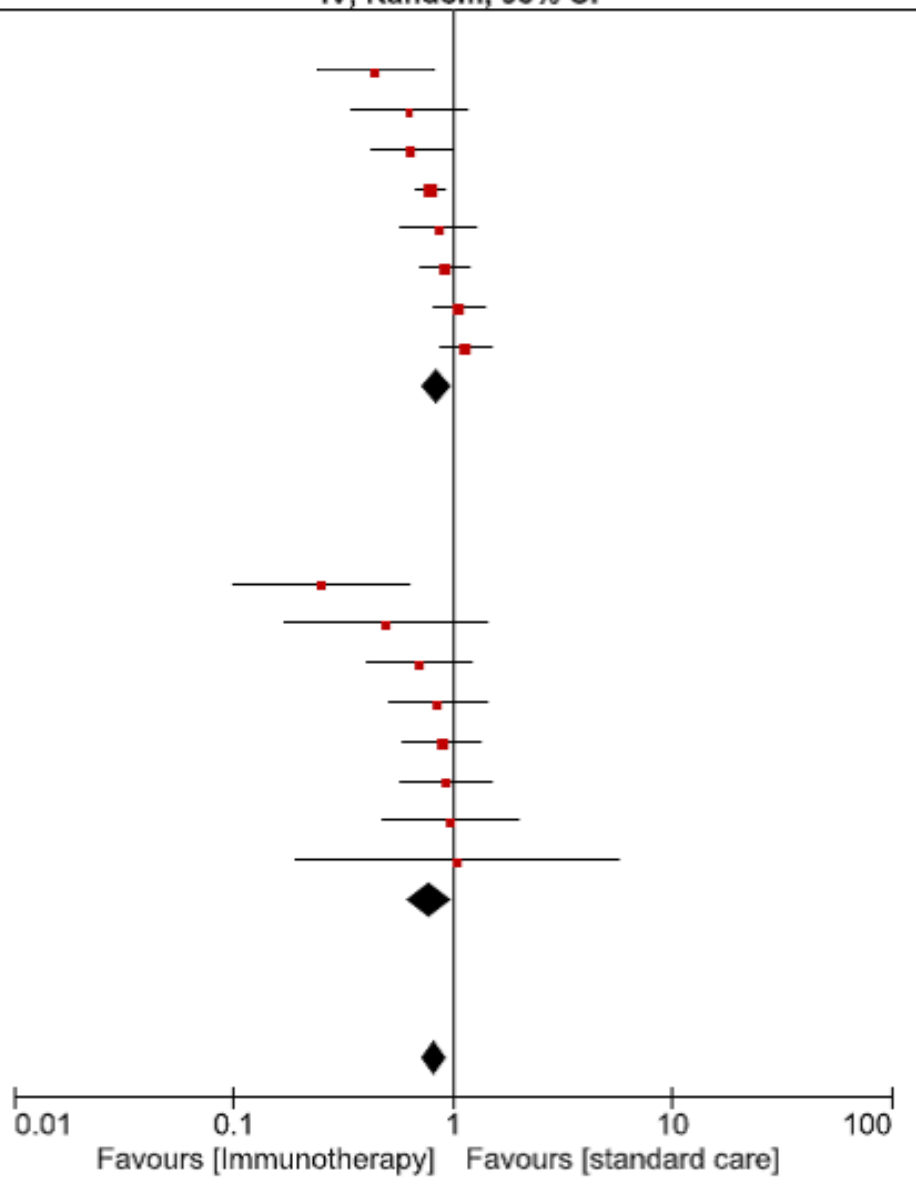

\section{Figure 2}

Meta-Analysis of Overall Survival in first line setting: (1) patients under the age of 75 (2) patients over the age of 75 
Hazard Ratio $\quad$ Hazard Ratio

Study or Subgroup Weight IV, Fixed, $95 \% \mathrm{Cl}$

1.1.1 Under 75 years

Checkmate 017

Keynote 040

$4.0 \% \quad 0.56[0.34,0.92]$

Checkmate 057

$5.3 \% \quad 0.57[0.37,0.88]$

Checkmate 025

Keynote 010

$8.7 \% \quad 0.63[0.45,0.88]$

$7.9 \% \quad 0.64[0.45,0.91]$

$42.9 \% \quad 0.64[0.55,0.74]$

Javelin Lung $200 \quad 19.3 \% \quad 0.89[0.71,1.12]$

Subtotal $(95 \% \mathrm{CI}) \quad 88.0 \% \quad 0.68[0.61,0.75]$

Heterogeneity: $\mathrm{Chi}^{2}=7.60, \mathrm{df}=5(\mathrm{P}=0.18) ; \mathrm{I}^{2}=34 \%$

Test for overall effect: $Z=7.20(P<0.00001)$

1.1.2 Over 75 years

$\begin{array}{lrr}\text { Keynote 010 } & 3.7 \% & 0.72[0.43,1.21] \\ \text { Checkmate 057 } & 1.8 \% & 0.90[0.43,1.88] \\ \text { Keynote 040 } & 1.0 \% & 1.13[0.42,3.04] \\ \text { Javelin Lung 200 } & 1.7 \% & 1.16[0.54,2.49] \\ \text { Checkmate 025 } & 2.5 \% & 1.23[0.66,2.29] \\ \text { Checkmate 017 } & 1.2 \% & 1.85[0.76,4.50] \\ \text { Subtotal (95\% Cl) } & \mathbf{1 2 . 0 \%} & \mathbf{1 . 0 2}[0.77,1.36]\end{array}$

Heterogeneity: $\mathrm{Chi}^{2}=4.08, \mathrm{df}=5(\mathrm{P}=0.54) ; \mathrm{I}^{2}=0 \%$

Test for overall effect: $Z=0.15(P=0.88)$

Total $(95 \% \mathrm{Cl})$

$100.0 \% \quad 0.71[0.64,0.79]$

Heterogeneity: $\mathrm{Chi}^{2}=18.59, \mathrm{df}=11(\mathrm{P}=0.07) ; \mathrm{I}^{2}=41 \%$

Test for overall effect: $Z=6.71(P<0.00001)$

Test for subgroup differences: $\mathrm{Chi}^{2}=6.92, \mathrm{df}=1(\mathrm{P}=0.009), \mathrm{I}^{2}=85.5 \%$

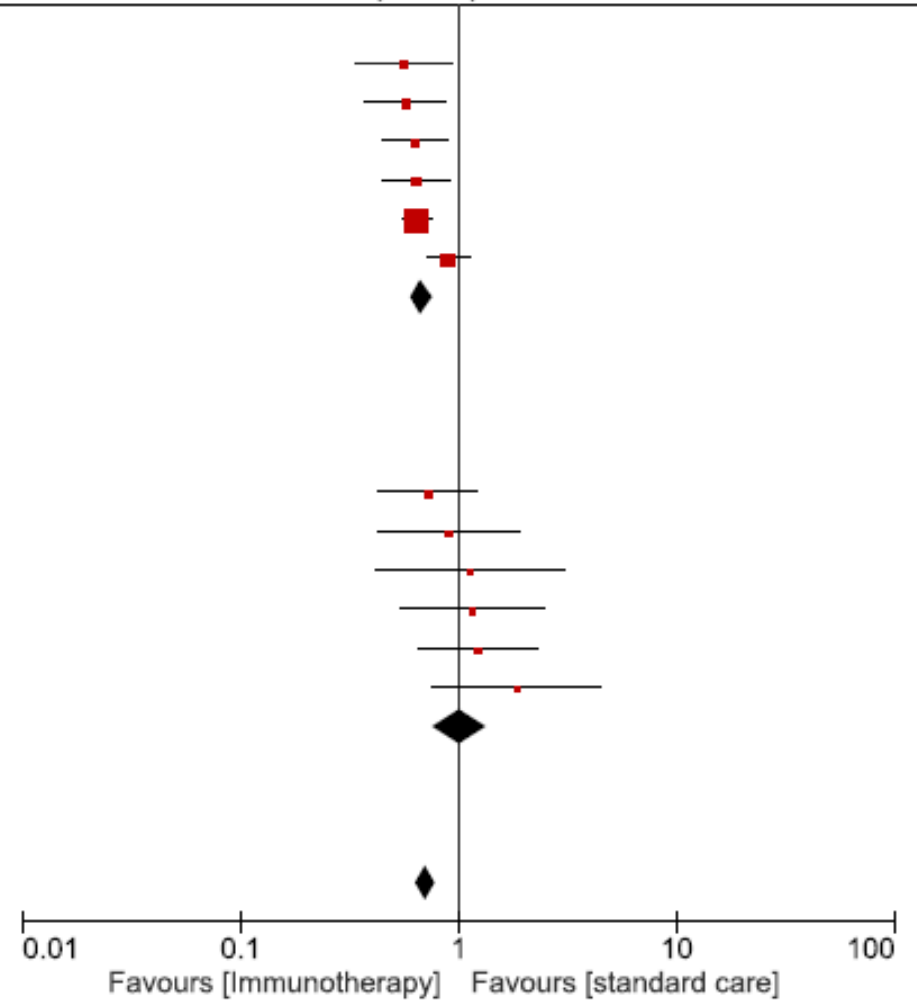

\section{Figure 3}

Meta-Analysis of Overall Survival in second line setting: (1) patients under the age of 75 (2) patients over the age of 75 